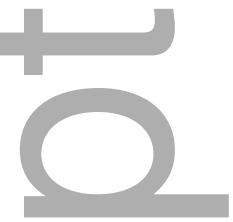

\title{
Maternal HPA-1a antibody level and its role in predicting the severity of Fetal/Neonatal Alloimmune Thrombocytopenia: A systematic review
}

Mette $\mathrm{Kjær}^{1,2}$, Gerald Bertrand ${ }^{3}$, Tamam Bakchoul ${ }^{4,5}$, Edwin Massey ${ }^{6}$, Jillian M. Baker ${ }^{7}$, Lani Lieberman ${ }^{8}$, Susano Tanael $^{9}$, Andreas Greinacher ${ }^{5}$, Michael F. Murphy ${ }^{10}$, Donald M. Arnold ${ }^{11}$, Shoma Baidya ${ }^{12}$, James Bussel ${ }^{13}$, Heather Hume ${ }^{14}$, Cécile Kaplan ${ }^{15}$, Dick Oepkes ${ }^{16}$, Greg Ryan $^{17}$, Helen Savoia ${ }^{18}$, Nadine Shehata ${ }^{9,19,20}$, and Jens Kjeldsen-Kragh ${ }^{1,21}$ on behalf of International Collaboration for Transfusion Medicine Guidelines

${ }^{1}$ Department of Laboratory Medicine, Diagnostic Clinic, University Hospital of North Norway, Troms $\varnothing$, Norway;

${ }^{2}$ Finnmark Hospital Trust, Hammerfest, Norway;

${ }^{3}$ Platelet Immunology Department, French Blood Services of Brittany, Rennes, France;

${ }^{4}$ Center for Clinical Transfusion Medicine, University of Tuebingen, Tuebingen, Germany;

${ }^{5}$ Institute of Immunology and Transfusion Medicine, University Hospital Greifswald, Greifswald, Germany;

${ }^{6}$ NHS Blood and Transplant, Bristol, United Kingdom;

${ }^{7}$ Hospital for Sick Children, St. Michael's Hospital, Toronto, ON, Canada;

${ }^{8}$ University Health Network, University of Toronto, Toronto, ON, Canada;

${ }^{9}$ Center for Innovation, Canadian Blood Services, Toronto, ON, Canada;

${ }^{10}$ NHS Blood and Transplant, Oxford University Hospitals and University of Oxford, Oxford, United Kingdom;

${ }^{11}$ Division of Hematology and Thromboembolism, McMaster University, Hamilton, ON, Canada;

${ }^{12}$ Australian Red Cross Blood Service, Brisbane, QLD, Australia;

${ }^{13}$ Weill Cornell Medicine, New York, NY, United States of America;

${ }^{14}$ Division of Hematology-Oncology, Centre Hospitalier Universitaire Sainte-Justine, University of Montreal, Montreal, QC, Canada;

${ }^{15}$ Retired, formerly Institut National de la Transfusion Sanguine, Paris, France; 
${ }^{16}$ Department of Obstetrics, Leiden University Medical Center, Leiden, The Netherlands;

${ }^{17}$ Fetal Medicine Unit, Mount Sinai Hospital, Toronto, ON, Canada;

${ }^{18}$ Royal Children's Hospital, Melbourne, VIC, Australia;

${ }^{19}$ Department of Medicine, and

${ }^{20}$ Department of Obstetric Medicine, Mount Sinai Hospital, Toronto, ON, Canada;

${ }^{21}$ Department of Clinical Immunology and Transfusion Medicine, Regional and University Laboratories Region Skåne, Lund, Sweden

Correspondence: M Kjær, Finnmark Hospital Trust, Hammerfest, Norway, e-mail: mette.kjaer@finnmarkssykehuset.no. Phone: +4746777368

Running title: HPA-1a antibodies and FNAIT severity

Text word count: 3309

Abstract word count: 229

Number of figures: 2

Number of tables: 2

Number of references: 41

Disclosures: MK and JKK are two of the founders and owners of Prophylix Pharma AS, a Norwegian biotech company coordinating the EU-funded PROFNAIT Consortium which is developing a prophylaxis against fetal and neonatal alloimmune thrombocytopenia. NS and DA are consultants for Canadian Blood Services. DO has received research funding to a project "Towards routine HPA-screening in Pregnancy". JB is a consultant of Baxalta, Superior Biologics. HS is a member of the Neonatal Alloimmune Thrombocytopenia Registry of the Transfusion Outcomes Research Collaborative (TORC), Australia. The remaining authors declare that they have no conflicts of interest.

Funding Source: Canadian Blood Services partially funded this study. Canadian Blood Services did not have any role in the design, analysis, and interpretation of the data or preparation, review, and approval of the manuscript. European Union's $7^{\text {th }}$ Framework Program also supported this work through the PROFNAIT project.

\section{Abstract}

BACKGROUND AND OBJECTIVES: In Caucasians, fetal/neonatal alloimmune thrombocytopenia (FNAIT) is most commonly due to maternal HPA-1a antibodies. HPA-1a typing followed by screening for anti-HPA-1a antibodies in HPA-1bb women may identify first pregnancies at risk. Our goal was to review results from previous published studies to examine whether the maternal antibody level to HPA-1a could be used to identify high-risk pregnancies.

MATERIALS AND METHODS: The studies included were categorized by recruitment strategies: screening of unselected pregnancies or samples analyzed from known or suspected FNAIT patients. 
RESULTS: Three prospective studies reported results from screening programs and 10 retrospective studies focused on suspected cases of FNAIT. In 8 studies samples for antibody measurement, performed by the monoclonal antibody immobilization of platelet antigen (MAIPA) assay, and samples for determining fetal/neonatal platelet count were collected simultaneously. In these 8 studies, the maternal antibody level correlated with the risk for severe thrombocytopenia. The prospective studies reported high negative predictive values (88-95\%), which would allow for the use of maternal anti-HPA-1a antibody level as a predictive tool in a screening setting, in order to identify cases at low risk for FNAIT. However, due to low positive predictive values reported in prospective as well as retrospective studies (54-97\%), the maternal antibody level is less suited for the final diagnosis and for guiding antenatal treatment.

CONCLUSION: HPA-1a antibody level has the potential to predict the severity of FNAIT.

Keywords: alloimmune thrombocytopenia, maternal HPA-1a antibodies, MAIPA, platelet, bleeding

\section{INTRODUCTION}

The frequency of severe fetal and neonatal alloimmune thrombocytopenia (FNAIT) $\left(<50 \times 10^{9} / \mathrm{L}\right)$ secondary to HPA-1a antibodies has been reported to be approximately $1 / 2500$ pregnancies.[1] Clinically, a fetus or neonate with severe FNAIT often displays unexpected bleeding during pregnancy or within a few hours of delivery.

Without screening of all pregnancies, there is currently no way to predict the occurrence of FNAIT other than identification of a sibling with FNAIT. Using the obstetric history as a predictor, with a diagnostic sensitivity of only $13 \%$, the majority of severe FNAIT cases are not detected until after delivery.[2] . Thus in a non screening situation, Tiller et al. reported that only 7-8 cases of FNAIT were detected per year compared with 53 cases when screening was applied.[3]

Development of non-invasive diagnostic tools that can be used to discriminate between pregnancies in need of antenatal treatment is crucial. The current approach by identifying neonates with FNAIT postnatally, precludes antenatal treatment and/or precautions during delivery, whereas an antenatal screening program would ideally allow both antenatal intervention and immediate treatment of severe FNAIT at birth of an affected neonate.

The challenge of an antenatal screening program is, however, to identify women in whom the risk of severe FNAIT is sufficiently high to justify active treatment during pregnancy to minimize the risk of bleeding complications secondary to FNAIT, whilst not exposing women with milder cases to unnecessary interventions.

The aim of this systematic review is to examine if a relationship can be identified between maternal anti-HPA-1a alloantibody concentration and fetal/neonatal platelet count, which could potentially serve as a non-invasive strategy to identity high-risk pregnancies.

\section{METHODS}

Study selection and data extraction 
The search was applied to the electronic databases MEDLINE, EMBASE and the Cochrane Library from 1946 to January 12, 2016 (Appendix A). Data were independently extracted by two authors (NS, ST).

The included studies met the following criteria: 1) an original study, 2) five or more pregnant women, 3) platelet count and HPA-1a antibody determination, and 4) published in English. Details from each included study are summarized in Appendix B. The included studies were divided into two categories: 1) 'Prospective studies' of 'unselected women' identified by an FNAIT screening program (HPA-1 typing followed by anti- HPA-1a antibody screening), and 2) 'Retrospective studies' of 'selected women' due to an FNAIT child.

All thrombocytopenic neonates $\left(<150 \times 10^{9} / \mathrm{L}\right)$ from these studies were included in this review, even those without clinical signs of bleeding.

\section{Assessment of quality}

The assessment of the quality of individual primary studies was based on the checklist developed by Fowkes and Fulton and considered the following; whether 1) there was an adequate description of the study population, 2) all eligible patients were screened, 3) a normal sample was included, 4) there were clear definitions of associations, 5) reproducibility of testing was assessed 6) missing data were reported.[4] The considerable heterogeneity in the measurement of study outcomes did not permit conduction of a meta-analysis; therefore, we performed a descriptive review of included studies. Strategies for inclusion of study subjects, the type of laboratory assay used and the time point of both maternal and fetal sampling were specially taken into consideration when analyzing the data.

\section{RESULTS}

\section{Study selection and characteristics}

A total of 5,940 publications were identified (Figure 1). Of these, 4,692 were screened after duplicates were removed and 93 full-text articles were assessed for eligibility. Sixty-six of the 93 did not report the population or outcome of interest and three were not published in English.

Finally, thirteen of the 27 studies had complete data[2, 5-16], the remainder were duplicates[17-21], did not address HPA-1a antibodies[22-25], screened all neonates[26], or did not have a sufficient sample size[27-30]. Three studies were prospective[2, 5, 7] and ten studies were retrospective.[6, 8-16] Appendix B describes the 13 studies that were included in this review. Appendix $\mathbf{C}$ details the 14 studies that were not included.

The assessment of the quality of studies is shown in Figure 2. Nine studies adequately described the study population.[2, 5-9, 11, 13, 15] Six studies included samples from non-FNAIT cases[2, 5, 8-10,12] and screened eligible patients.[2, 5-8, 12]

Four studies reported missing data[2, 4, 8, 10] and three studies assessed reproducibility of testing.[2, 8,11$]$

The majority of studies defined severe FNAIT as platelets $<50 \times 10^{9} / \mathrm{L}$. Severe FNAIT was not defined in three studies.[10, 12, 15] 
The studies differed in three key aspects: i) the assays used, ii) the time point at sampling and iii) the populations screened. Ten studies used the MAIPA assay.[2, 5, 6, 8-11, 13, 14, 16] Other methods used were ELISA[7, 12, 16], the platelet immunofluorescence test (PIFT)[2, 10, $12,15]$ the ${ }^{51} \mathrm{Cr}$ release test[12] and the chemiluminescence assay.[8]

Antibody testing was scheduled across various weeks of gestation. Antibody measurement was conducted once in five studies[8-10, 14, 16], and more than once in seven studies.[2, 5, 7, 11-13, 15] The frequency of antibody testing was not reported in one study.[6]

Three studies conducted HPA-1 typing followed by antibody screening and quantitation in unselected pregnancies.[2, 5, 7] Ten studies analyzed samples of known or suspected FNAIT.[6, 8-16]

The assay and time point of sampling were taken into consideration when summarizing and discussing the results i.e. evaluating studies that used the same laboratory methods, as well as evaluating results from retrospective studies that reported antibody concentrations and fetal or newborn platelet counts at the same time point when possible.

Lastly, the results were grouped and described separately i.e. prospective screening studies of unselected pregnancies and studies including newly diagnosed FNAIT patients and/or follow-up of women with a history of FNAIT, i.e. retrospective studies.

\section{Prospective screening studies on unselected pregnancies}

Details of the three prospective studies that screened and reported quantitative results from unselected immunized pregnancies (a total of 235/125 000 screened pregnancies) are presented in Table 1.[2, 5, 7] None of these women was treated with intravenous immune globulin (IVIG) during pregnancy. Severely thrombocytopenic neonates (with or without bleeding symptoms) were treated with compatible platelet transfusion immediately after birth.

Antibody level to predict FNAIT: Williamson described that fetal thrombocytopenia $\left(<50 \times 10^{9} / \mathrm{L}\right)$ in the third trimester was associated with maternal HPA-1a antibody level (titers $\geq 1: 32$, positive predictive value (PPV) $75 \%$ and negative predictive value (NPV) 88\%).[5] Killie also reported a correlation between neonatal platelet count $\left(<50 \times 10^{9} / \mathrm{L}\right)$ and maternal HPA-1a antibody level at the time of delivery, $\mathrm{R}^{2}=0.49$. [2] The PPV and NPV of severe FNAIT $\left(<50 \times 10^{9} / \mathrm{L}\right)$ using an antibody level of $3 \mathrm{IU} / \mathrm{mL}$ when screening unselected pregnancies were $54 \%$ (95\% CI 43-63\%) and 95\% (95\% CI 86-98\%), respectively.[2] In 76 pregnancies with maternal HPA-1a antibody levels $<3 \mathrm{IU} / \mathrm{mL}$, four neonates were severely thrombocytopenic (platelet counts of $16,30,36$ and $45 \times 10^{9} / \mathrm{L}$ ) but did not have any bleeding symptoms.[2] Both studies used MAIPA to analyze the HPA-1a antibody levels.[2, 5] The third study by Bessos did not find any correlation between newborn platelet counts and the HPA-1a antibody concentration using an in-house ELISA for HPA-1a antibody quantitation, $\mathrm{R}^{2}=0.14$.[7] However, a correlation between antibody level and platelet count was identified in a comparable subsequent study using MAIPA, $\mathrm{R}^{2}=0.42$. In this study, Bessos reanalyzed 14 samples from their previous study together with 12 samples from the study by Killie 2008 (Table 1).[19] Hence, all studies (n=3) reported that the maternal antibody level at delivery correlated with the newborn platelet count when using quantitative MAIPA. 


\section{Retrospective studies on suspected FNAIT}

The ten studies focusing on suspected patients with FNAIT included a total of 566 women with HPA-1a antibodies.[6, 8-16] These studies included patients who were treated antenatally with either IVIG (with or without steroids) or with intrauterine platelet transfusions. Eight of the ten studies reported either titration or quantification of HPA-1a antibodies (Table 2). In the four studies that reported results obtained from the second trimester, blood samples were collected from the pregnant mother and the fetus at the same time points; whereas in the five studies that reported results from sampling at birth and/or the $3^{\text {rd }}$ trimester, samples were only collected simultaneously in three studies.[6, 8-13, 15]

Antibody level to predict severity of FNAIT: Three studies investigated the HPA-1a antibody level by titration of the samples using either PIFT or ELISA.[10, 12, 15] One of these studies[15] did not examine if there was any correlation between antibody titer and platelet count while the two other studies[10, 12] indicated that there was no correlation between the HPA-1a antibody level and neonatal platelet count. Five studies quantified maternal HPA-1a antibodies by quantitative MAIPA.[6, 8, 9, 11, 13] Four of these five studies, which included a total of 313 pregnancies, identified a statistically significant relationship (p-values: $0.002-0.046)$ between HPA-1a antibody level and fetal or neonatal platelet count $\left(<20 \times 10^{9} / \mathrm{L}\right.$ or $<50 \times 10^{9} / \mathrm{L}$, see Table 2).[6, 9, 11, 13] From the four studies that reported an association, Sainio did not find a statistically significant correlation in samples taken postnatally in 72 index patients, but identified a statistically significant correlation between maternal HPA-1a antibody level during the second trimester and the corresponding fetal platelet count.[11] In addition, maternal HPA-1a antibody level was significantly higher for those delivering neonates with bleeding symptoms (ICH or mild bleeding symptoms) than in mothers of neonates with FNAIT that there were no evidence of bleeding. Killie reported a significant difference in maternal antibody levels at delivery between cases where neonates were severely thrombocytopenic and neonates with normal platelet count.[9] Bertrand reported that an antibody level o $\$ 250 \mathrm{AU} / \mathrm{mL}$ (corresponding to $31 \mathrm{IU} / \mathrm{mL}[18]$ ) correlated with severe thrombocytopenia in the fetus before the start of treatment $\left(\mathrm{p}=0.0021\right.$ ). [6] At this level, PPV and NPV for a platelet count of $50 \times 10^{9} / \mathrm{L}$ or less were $94 \%$ and $60 \%$, respectively.[6] The same group subsequently reported that in pregnancies treated with IVIG, a mean antibody level throughout pregnancy (area under the curve, AUC) $>23 \mathrm{IU} / \mathrm{mL}$ correlated with treatment failure (newborn platelet count $\leq 50 \times 10^{9} / \mathrm{L}$ ). [13] By using an antibody level of $23 \mathrm{IU} / \mathrm{mL}$ as cut-off, the PPV and NPV of therapy failure were 67 and $86 \%$, respectively.

The last of the five studies included 97 newly diagnosed and 36 patients with known FNAIT, and did not find any relationship between anti-HPA-1a antibody levels and platelet count in newly diagnosed patients.[8] However, in 22/36 patients who were treated antenatally, maternal HPA-1a antibody levels were reported to correlate with fetal platelet count (after fetal blood sampling [FBS]). The correlation co-efficient was not reported. Overall four of five studies, which used quantitative MAIPA found that the maternal antibody level in second trimester correlated with the fetal platelet count in second trimester (4/5). The last study did not investigate fetal platelet count during second trimester, but reported that maternal antibody level measured at time of delivery correlated with platelet count in the newborn.[9] 
It is not known if and how antenatal IVIG treatment potentially affects measurements of anti-HPA-1a antibodies. However, a decrease in HPA-1a antibody concentrations has been observed during pregnancies of IVIG-treated women [6] as well as in untreated women [2], suggesting that the decrease in antibody level may not be associated with IVIG therapy.

\section{DISCUSSION}

\section{Main findings}

In this descriptive systematic review, we found that most studies quantifying HPA-1a antibodies by the MAIPA assay reported a correlation between antibody level and severity of FNAIT; whereas studies in which antibody analysis was done by PIFT or ELISA could not document such a relationship, suggesting that these methods may not be as suitable for quantitative analysis. This is supported by the study by Bessos who compared ELISA and MAIPA and found that the severity of FNAIT was significantly associated with the HPA-1a antibody level when using MAIPA, but not when an in-house ELISA was used.[19] Another important finding was that timing of the blood sample for antibody determination from mother and fetus/newborn seems essential since a correlation was only observed in those studies that reported the same time point for fetal/newborn platelet count sampling and maternal antibody detection/quantitation.

Results from prospective screening studies using the MAIPA technique[2, 5] (a total of approximately 125,000 pregnancies) showed that among 256 HPA-1a-immunized pregnancies, HPA-1a antibody levels in the third trimester or at delivery correlated with the newborn platelet count, suggesting that the maternal HPA-1a antibody level in the third trimester has the potential to be used as a predictive tool, and used as guideline for mode of delivery and to have compatible HPA-1bb platelets available in case of bleeding in the neonate.

A significant association (all $\mathrm{p}<0.05$ ) between the fetal platelet count and maternal antibody level quantified by MAIPA could also be demonstrated in pregnancies known to be at risk of FNAIT due to a previous child with FNAIT, when maternal and fetal sampling was performed at the same time during the second trimester.[6, 8, 9, 11] The low PPV and NPV would not allow for the use of maternal antibody level to determine a final diagnosis of severe FNAIT (defined as $<20 \times 10^{9} / \mathrm{L}$ or $<50 \times 10^{9} / \mathrm{L}$ in the studies) or to be used to establish treatment regimens. Bertrand suggests that the maternal antibody level throughout pregnancy (area under the curve, AUC) might be used to follow the effect of IVIG treatment.[13]

\section{Strength and limitations}

A strength of this systematic review is that study populations were categorized by FNAIT risk and compared separately; i.e. results from studies screening unselected pregnancies (prospective studies) and from studies focusing on newly diagnosed FNAIT patients and pregnancies with a known risk of FNAIT (retrospective studies). This has been an important bias in previous study reports. In retrospective studies, cases have been selected who have been diagnosed with FNAIT in the fetus/newborn, and thus, it is not surprising that the majority of these women will have higher antibody levels than women in prospective studies, since the latter studies included all HPA-1a-immunized women irrespective of fetal/neonatal symptoms. It is 
therefore not surprising there is a better chance of finding an association between antibody levels and fetal/neonatal platelet counts in prospective studies, as compared with retrospective studies, and similarly, it is not surprising that an effort of defining a clinically relevant antibody cut-off level will differ between these two patient populations.

In general, measurements reported as fluorescence intensity, optical density, titer or arbitrary units would depend on the in-house assay sensitivity and would not allow for comparison between laboratories. Results could only be compared directly when an international standard was used as a reference and measurements were reported in IU/mL. As a result, there are two major limitations of the studies included in this review that make it difficult to draw definitive conclusions. Firstly, different methods were used to quantify anti-HPA-1a levels and the number of studies reporting HPA-1a antibody level in IU/mL was small (4/13). Secondly, the time of sampling varied considerably. Samples taken at different time points cannot be compared directly, primarily because the transfer of maternal IgG across the placenta varies with gestational age. The transfer of normal and pathogenic IgG from the mother to her fetus begins as early as the end of the first trimester and increases as the pregnancy advances.[31] Therefore, the amount of HPA-1a antibodies to which the fetus is exposed, may be related to both maternal antibody concentration and gestational age.

The studies in the current review correlated antibody concentration and platelet count using a low platelet count as a surrogate for bleeding risk. Bleeding is indeed much more common in neonates with very low platelet counts but many fetuses with low platelet counts seem not to bleed. Both a defective hemostatic system as well as endothelial damage are necessary requirements for bleeding to occur. Thus, isolated thrombocytopenia, as such, may not cause harm in the newborn unless the endothelium is damaged. This may explain why some newborns with severe thrombocytopenia do not bleed. Recently, it was demonstrated that HPA1a antibodies in women who have had a fetus/child with FNAIT-associated ICH bind to $\alpha$ Vß3 on endothelial cells, and that these antibodies in vitro can induce endothelial apoptosis. These antibodies were not present in HPA-1a-immunized women whose fetus/child had FNAIT but no ICH.[32] Unfortunately, the current MAIPA assays do not distinguish between these different specificities of the HPA-1a antibodies. Moreover, the reactivity of antibodies measured by MAIPA or similar techniques is always a composite of antibody amount, specificity and avidity. Moreover, the exact binding sites (epitopes) for the HPA-1a antibodies would be important, since binding sites might alter binding to and/or signaling through the fibrinogen receptor, and thus may have influence on FNAIT severity and bleeding tendency.[33] Further, low avidity antibodies can have biological effects as they are not washed away in vivo as opposed to in vitro, and such antibodies may account for those few cases where a fetus/child bleeds despite the MAIPA assay only detected low levels of anti-HPA-1a.

\section{Implications}

FNAIT has been regarded as the platelet counterpart of hemolytic disease of the fetus and newborn (HDFN). For decades, measurement of the maternal anti-D level, either as titer or as $\mathrm{IU} / \mathrm{mL}$, has been used in Europe and North America to determine when an RhD-immunized woman is referred to a fetal medicine unit for monitoring and eventual treatment. An RhD- 
alloimmunized pregnant woman is referred to a fetal medicine unit for monitoring the middle cerebral artery peak systolic velocity (MCA PSV) when the antibody level exceeds $4 \mathrm{IU} / \mathrm{mL}$. Invasive investigation or treatment may be required when the anti-D level exceeds $15 \mathrm{IU} / \mathrm{mL}$, but this is ultimately determined by the MCA PSV levels.[34-36]. . Results from the prospective studies suggest that HPA-1a antibody levels might have a comparable future role as predictor for fetuses with increased risk for FNAIT. As there remains interlaboratory variation in measurement in the measurement of the anti-D titer [37], some of the inconsistencies in antiHPA-1a antibody titer we found in some of reports may represent a similar occurrence. Although a gold standard imaging modality is not yet available, and there is a lack of consensus on how to treat risk pregnancies that are identified by screening, anti-HPA-1a levels may identify pregnancies to be referred to specialists in fetal-maternal medicine. Hence, if screening for FNAIT is implemented, measurements of HPA-1a antibody levels could potentially be used for risk stratification of pregnancies and could guide the clinicians in order to avoid invasive procedures in pregnancies with low risk, and for planning the route of delivery and treatment of high risk pregnancies. Preliminary data suggest $[36,37]$ an antibody cut-off of $3 \mathrm{IU} / \mathrm{mL}$ may potentially be used for risk assessment.

Studies have shown that by standardizing quantitative MAIPA and by expressing antiHPA-1a levels in IU/mL, it is possible to obtain comparable results across laboratories[38, 39], and therefore, the differences in HPA-1a antibody cut off level $(3 \mathrm{IU} / \mathrm{mL}$ at delivery vs 30 $\mathrm{IU} / \mathrm{mL}$ in the second trimester[6,8]) between prospective and retrospective studies may not necessarily be due to inter-laboratory variability. Instead, the difference between the identified antibody threshold may be due to variable trans-placental transportation of IgG during pregnancy. In the second trimester, the fetal $\operatorname{IgG}$ level is only $5 \%-10 \%$ of the maternal $\operatorname{IgG}$ concentration; whereas, later in the third trimester, $\operatorname{IgG}$ concentration is almost identical in the mother and fetus.[40] It is also important to be aware that maternal antibody levels increase shortly after delivery and post-partum sampling cannot be used to study the correlation between maternal antibody levels and newborn platelet count.

Although the HPA-1a-antibody concentration, as measured by the MAIPA assay, appears to be associated with the degree of thrombocytopenia in FNAIT, there are shortcomings which make it difficult to predict individual risk for bleeding. Thus, more studies are needed to define antibody characteristics that give higher PPV or NPV for bleeding risk; preferentially predictive values in the same range as MCA PSV for the prediction of anaemia in women who are RhDimmunized. Future studies should be prospective, should report the exact time point of sampling (which ideally would also be standardized), should perform quantitative HPA-1a analysis by the MAIPA assay, should report HPA-1a antibody levels in IU/mL using WHO HPA-1a international standards[41], and should measure the antibody concentration prior to antenatal treatment as well as during antenatal treatment. 


\section{ACKNOWLEDGMENTS}

\section{International Collaboration for Transfusion Medicine Guidelines (ICTMG) Members -}

Shubha Allard, MD, FRCP, FRCPath, Barts Health NHS Trust and NHS Blood \& Transplant; Celso Bianco, MD, formerly with America's Blood Centres; Jeannie Callum, BA, MD, FRCPC, CTBS, University of Toronto, Canada; Veerle Compernolle, MD, PhD, Belgian Red Cross, Flanders, Belgium; USA; Dean Fergusson, MHA, PhD, University of Ottawa, Canada; Mark Fung, MD, PhD, Fletcher-Allen Health Care, USA; Andreas Greinacher, MD, University of Greifswald, Germany; Heather Hume, MD, FRCPC, Université de Montréal, Canada; Lani Lieberman, MD, University of Toronto, Canada; Michael F. Murphy, MD, FRCP, FRCPath, FFPath, University of Oxford, UK; Susan Nahirniak, MD, FRCPC, University of Alberta, Canada; Katerina Pavenski, MD, FRCPC, University of Toronto, Canada; Joanne Pink, MBBS, FRACP, FRCPA, Australian Red Cross Blood Services, Australia; Nadine Shehata, MD, FRCPC, MSc, University of Toronto, Canada; Cynthia SoOsman, Groene Hart Ziekenhuis, Netherlands Simon J. Stanworth, MA, MRCP, DPhil, FRCPath, University of Oxford, UK; Zbigniew M. Szczepiorkowski, MD, PhD, DartmouthHitchcock Medical Centre, USA; Susano Tanael, MD MMA, Canadian Blood Services, Canada; Erica Wood, MBBS, FRACP, FRCPA, Monash University, Australia.

The authors thank Elizabeth Uleryk for the search strategy; and Sylvia Torrance and Kimberly Figures for administrative assistance.

\section{AUTHORSHIP}

Contributions: MK, GB and JKK drafted the initial manuscript. JB, EM, LL, NS and TB performed the data search. MK extracted and analyzed the data, supported by ST, NS and JKK. AG, MM, DA, SB, JB, CK, HH, DO, GR and HS participated in the interpretation and revision of critically important contents of the review and gave final approval of the version to be submitted.

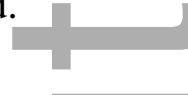

\section{REFERENCES}

1 Kamphuis MM, Paridaans N, Porcelijn L, et al.: Screening in pregnancy for fetal or neonatal alloimmune thrombocytopenia: systematic review. BJOG 2010; 117: 1335-43.

2 Killie MK, Husebekk A, Kjeldsen-Kragh J, et al.: A prospective study of maternal antiHPA 1a antibody level as a potential predictor of alloimmune thrombocytopenia in the newborn. Haematologica 2008; 93: 870-7.

3 Tiller H, Killie MK, Skogen B, et al.: Neonatal alloimmune thrombocytopenia in Norway: poor detection rate with nonscreening versus a general screening programme. BJOG 2009; 116: 594-8. 
Fowkes FG, Fulton PM: Critical appraisal of published research: introductory guidelines. BMJ 1991; 302: 1136-40.

Williamson LM, Hackett G, Rennie J, et al.: The natural history of fetomaternal alloimmunization to the platelet-specific antigen HPA-1a (P1A1, Zwa) as determined by antenatal screening. Blood 1998; 92: 2280-7.

Bertrand G, Martageix C, Jallu V, et al.: Predictive value of sequential maternal antiHPA-1a antibody concentrations for the severity of fetal alloimmune thrombocytopenia. J Thromb Haemost 2006; 4: 628-37.

Bessos H, Turner M, Urbaniak SJ: Is there a relationship between anti-HPA-1a concentration and severity of neonatal alloimmune thrombocytopenia? Immunohematology 2005; 21: 102-9.

8 Ghevaert C, Campbell K, Stafford P, et al.: HPA-1a antibody potency and bioactivity do not predict severity of fetomaternal alloimmune thrombocytopenia. Transfusion 2007; 47: 1296-305.

9 Killie MK, Husebekk A, Kaplan C, et al.: Maternal human platelet antigen-1a antibody level correlates with the platelet count in the newborns: a retrospective study. Transfusion 2007; 47: 55-8.

10 Proulx C, Filion M, Goldman M, et al.: Analysis of immunoglobulin class, IgG subclass and titre of HPA-1a antibodies in alloimmunized mothers giving birth to babies with or without neonatal alloimmune thrombocytopenia. Br J Haematol 1994; 87: 813-7.

11 Sainio S, Javela K, Tuimala J, et al.: Usefulness of maternal anti-HPA-1a antibody quantitation in predicting severity of foetomaternal alloimmune thrombocytopenia. Transfus Med 2013; 23: 114-20.

12 McFarland JG, Frenzke M, Aster RH: Testing of maternal sera in pregnancies at risk for neonatal alloimmune thrombocytopenia. Transfusion 1989; 29: 128-33.

13 Bertrand G, Petermann R, Kaplan C: Prediction of IVIG treatment efficiency in fetal/neonatal alloimmune thrombocytopenia. Blood 2014; 124: 654-5.

14 Giers G, Wenzel F, Fischer J, et al.: Retrospective comparison of maternal vs. HPAmatched donor platelets for treatment of fetal alloimmune thrombocytopenia. Vox Sang 2010; 98: 423-30.

15 Kanhai HH, Porcelijn L, van Zoeren D, et al.: Antenatal care in pregnancies at risk of alloimmune thrombocytopenia: report of 19 cases in 16 families. Eur J Obstet Gynecol Reprod Biol 1996; 68: 67-73.

16 Taaning E, Petersen S, Reinholdt J, et al.: Neonatal Immune Thrombocytopenia Due to Allo-or Autoantibodies: Clinical and Immunological Analysis of 83 Cases. Platelets 1994; 5: 53-8.

17 Killie MK, Salma W, Bertelsen E, et al.: Quantitative MAIPA: Comparison of different MAIPA protocols. Transfus Apher Sci 2010; 43: 149-54.

18 Bertrand G, Drame M, Martageix C, et al.: Prediction of the fetal status in noninvasive management of alloimmune thrombocytopenia. Blood 2011; 117: 3209-13. 

assays in the measurement of maternal anti-HPA-1a antibody in neonatal alloimmune thrombocytopenia (NAIT). Transfus Apher Sci 2008; 39: 221-7. anti-HPA 1a antibodies; the level of maternal antibodies predicts the severity of thrombocytopenia in the newborn. BJOG 2000; 107: 691-4.

21 Mawas F, Wiener E, Williamson LM, et al.: Immunoglobulin G subclasses of anti-human platelet antigen 1a in maternal sera: relation to the severity of neonatal alloimmune thrombocytopenia. Eur J Haematol 1997; 59: 287-92.

Kurz M, Stockelle E, Eichelberger B, et al.: IgG titer, subclass, and light-chain phenotype of pregnancy-induced HPA-5b antibodies that cause or do not cause neonatal alloimmune thrombocytopenia. Transfusion 1999; 39: 379-82.

23 Ohto H, Miura S, Ariga H, et al.: The natural history of maternal immunization against foetal platelet alloantigens. Transfus Med 2004; 14: 399-408.

24 Panzer S, Auerbach L, Cechova E, et al.: Maternal alloimmunization against fetal platelet antigens: a prospective study. Br J Haematol 1995; 90: 655-60.

25 Ohto H, Yamaguchi T, Takeuchi C, et al.: Anti-HPA-5b-induced neonatal alloimmune thrombocytopenia: antibody titre as a predictor. Collaborative Study Group. $\mathrm{Br} J$ Haematol 2000; 110: 223-7.

26 Fratellanza G, Fratellanza A, Paesano L, et al.: Fetoneonatal alloimmune thrombocytopenia (FNAIT): our experience. Transfus Apher Sci 2006; 35: 111-7.

27 Blanchette VS, Chen L, de Friedberg ZS, et al.: Alloimmunization to the PlA1 platelet antigen: results of a prospective study. Br J Haematol 1990; 74: 209-15.

28 Davoren A, McParland P, Crowley J, et al.: Antenatal screening for human platelet antigen-1a: results of a prospective study at a large maternity hospital in Ireland. BJOG 2003; 110: 492-6.

29 Doughty HA, Murphy MF, Metcalfe P, et al.: Antenatal screening for fetal alloimmune thrombocytopenia: the results of a pilot study. Br J Haematol 1995; 90: 321-5.

30 Kaplan C, Daffos F, Forestier F, et al.: Management of alloimmune thrombocytopenia: antenatal diagnosis and in utero transfusion of maternal platelets. Blood 1988; 72: 340-3.

31 Lewis D TW: The physiologic immunodeficiency of immaturity.; in Stiehm E. OH, Winkelstein J., (ed) Immunologic Disorders in Infants and Children. Elsevier Saunders, 2004: p. 687-760.

32 Santoso S, Wihadmadyatami H, Bakchoul T, et al.: Antiendothelial alphavbeta3 Antibodies Are a Major Cause of Intracranial Bleeding in Fetal/Neonatal Alloimmune Thrombocytopenia. Arterioscler Thromb Vasc Biol 2016; 36: 1517-24.

33 Refsum E, Meinke S, Gryfelt G, et al.: Adding to the complexity of fetal and neonatal alloimmune thrombocytopenia: Reduced fibrinogen binding in the presence of anti-HPA1a antibody and hypo-responsive neonatal platelets. Thromb Res 2018; 162: 69-76.

34 Guidelines for blood grouping and red cell antibody testing during pregnancy. British Committee for Standards in Haematology, Blood Transfusion Task Force. Transfus Med 1996; 6: 71-4. 

Parker J, et al.: Guideline for blood grouping and antibody testing in pregnancy. Transfus Med 2007; 17: 252-62.

36 White J, Qureshi H, Massey E, et al.: Guideline for blood grouping and red cell antibody testing in pregnancy. Transfus Med 2016; 26: 246-63.

37 Bachegowda LS, Cheng YH, Long T, et al.: Impact of Uniform Methods on Interlaboratory Antibody Titration Variability: Antibody Titration and Uniform Methods. Arch Pathol Lab Med 2017; 141: 131-8.

38 Bertrand G, Jallu V, Gouet M, et al.: Quantification of human platelet antigen-1a antibodies with the monoclonal antibody immobilization of platelet antigens procedure. Transfusion 2005; 45: 1319-23.

39 Bertrand G, Bakchoul T, Javela K, et al.: Interlaboratory workshop on anti-HPA-1a alloantibody quantification with the mAb-specific immobilization of platelet antigen technique. J Thromb Haemost 2012; 10: 1172-4.

40 Malek A, Sager R, Kuhn P, et al.: Evolution of maternofetal transport of immunoglobulins during human pregnancy. Am J Reprod Immunol 1996; 36: 248-55.

41 Allen D, Rigsby P, Bessos H, et al.: Collaborative study to establish the first international standard for quantitation of anti-HPA-1a. Vox Sang 2005; 89: 100-4.

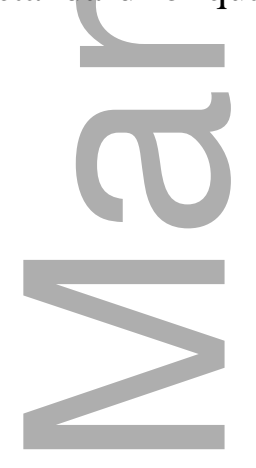

\section{TABLES}

Table 1 Characteristics and performance; samples collected by screening unselected pregnancies

Table 2 Characteristics and performance; samples collected retrospectively from known or suspected FNAIT cases

\section{FIGURE}

Figure 1 Flow diagram of included studies

Figure 2 Quality assessment of included studies 
Table 1 Characteristics and performance; samples collected by screening unselected pregnancies

\begin{tabular}{|c|c|c|c|c|c|c|c|c|c|}
\hline $\begin{array}{l}\text { First author, year of } \\
\text { publication } \\
\text { (number of pregnancies } \\
\text { screened) }\end{array}$ & $\begin{array}{c}\text { No. of } \\
\text { pregnancies }\end{array}$ & Method & $\begin{array}{l}\text { Time of } \\
\text { sampling }\end{array}$ & $\begin{array}{c}\text { Platelet } \\
\text { count cut-off }\end{array}$ & $\begin{array}{l}\text { Positive } \\
\text { predictive } \\
\text { value }\end{array}$ & $\begin{array}{l}\text { Negative } \\
\text { predictive } \\
\text { value }\end{array}$ & $\begin{array}{l}\text { Antibody } \\
\text { cut-off }\end{array}$ & $\mathrm{R}^{2}$ & $\begin{array}{c}\mathrm{p} \\
\text { value }\end{array}$ \\
\hline \multirow{2}{*}{$\begin{array}{l}\text { Williamson LM, } 1998 \\
(24 \text { 417) }\end{array}$} & 25 & MAIPA & $3^{\text {rd }}$ trimester & \multirow[t]{2}{*}{$<50 \times 10^{9} / \mathrm{L}$} & $75 \%$ & $88 \%$ & Titer: 32 & - & 0.004 \\
\hline & 13 & MAIPA & $1^{\text {st }}$ trimester & & - & - & Titer: 32 & - & NS \\
\hline $\begin{array}{l}\text { Killie MK, } 2008 \\
(100448)\end{array}$ & 161 & MAIPA & $\begin{array}{c}\text { At birth and at } \\
\text { weeks } 22 \text { and } \\
34\end{array}$ & $<50 \times 10^{9} / \mathrm{L}$ & $54 \%$ & $95 \%$ & $3 \mathrm{IU} / \mathrm{mL}$ & 0.49 & 0.001 \\
\hline $\begin{array}{l}\text { Bessos H, } 2005 \\
(26506)\end{array}$ & 28 & ELISA & At birth & NR & - & - & - & $<0.01$ & NS \\
\hline Bessos H, 2008* & 26 & MAIPA & At birth & NR & - & - & - & 0.42 & 0.002 \\
\hline
\end{tabular}

MAIPA, monoclonal antibody immobilization of platelet antigen; NR, not reported; NS, not significant; $\mathrm{R}^{2}$, coefficient of determination.

*The study compared results from 26 samples (from Bessos et al. 2005 and Killie et al. 2008) blindly quantified by both ELISA

This article is protected by copyright. All rights reserved 
and MAIPA. This study was not included in the systematic review since it includes duplicates from Bessos et al. 2005 and

Killie et al. 2008.

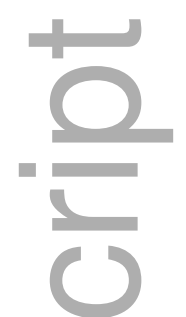

Table 2 Characteristics and performance; samples collected retrospectively from known or suspected FNAIT cases

\begin{tabular}{|c|c|c|c|c|c|c|c|c|c|}
\hline $\begin{array}{c}\text { First author, year of } \\
\text { publication }\end{array}$ & $\begin{array}{c}\text { No. of } \\
\text { pregnancies }\end{array}$ & Method & $\begin{array}{l}\text { Time of } \\
\text { sampling }\end{array}$ & $\begin{array}{c}\text { Platelet } \\
\text { count cut-off }\end{array}$ & $\begin{array}{l}\text { Positive } \\
\text { predictive } \\
\text { value }\end{array}$ & $\begin{array}{l}\text { Negative } \\
\text { predictive } \\
\text { value }\end{array}$ & $\begin{array}{l}\text { Antibody } \\
\text { cut-off }\end{array}$ & $\mathrm{R}^{2}$ & $\begin{array}{c}\mathrm{p} \\
\text { value }\end{array}$ \\
\hline McFarland JG, 1989 & 17 & $\begin{array}{l}\text { PIFT/ } \\
\text { ELISA }\end{array}$ & $\begin{array}{c}1^{\text {st }}, 2^{\text {nd }} \& 3^{\text {rd }} \\
\text { trimester }\end{array}$ & NR & - & - & - & - & NR \\
\hline Proulx C, 1994 & 36 & ELISA & At birth & NR & - & - & - & $<0.01$ & NS \\
\hline Bertrand G, & 27 & MAIPA & $\begin{array}{l}2^{\text {nd }} \& 3^{\text {rd }} \\
\text { trimester }\end{array}$ & $\leq 50 \times 10^{9} / \mathrm{L}$ & $94 \%$ & $60 \%$ & $\begin{array}{c}31 \mathrm{IU} / \\
\mathrm{mL}\end{array}$ & - & 0.002 \\
\hline Killie MK, 2 & 102 & MAIPA & At birth & $\begin{array}{l}<25 \times 10^{9} / \mathrm{L} \\
\& 25- \\
150 \times 10^{9} / \mathrm{L}\end{array}$ & - & - & - & - & 0.007 \\
\hline Ghevaert C, 2007 & 97 & MAIPA & At birth & $<50 \times 10^{9} / \mathrm{L}$ & - & - & - & - & NS \\
\hline
\end{tabular}

This article is protected by copyright. All rights reserved 


\begin{tabular}{|c|c|c|c|c|c|c|c|c|c|}
\hline J & 22 & MAIPA & $\begin{array}{l}2^{\text {nd }} \& 3^{\text {rd }} \\
\text { trimester }\end{array}$ & $<20 \times 10^{9} / \mathrm{L}$ & $90 \%$ & $66 \%$ & $\begin{array}{c}30 \mathrm{IU} / \\
\mathrm{mL}\end{array}$ & - & - \\
\hline \multirow{2}{*}{ Sainio S, 2013} & 72 & MAIPA & At birth & $<20 \times 10^{9} / \mathrm{L}$ & $80 \%$ & $17 \%$ & - & - & 0.074 \\
\hline & 16 & MAIPA & $2^{\text {nd }}$ trimester & $<20 \times 10^{9} / \mathrm{L}$ & $90 \%$ & $31 \%$ & - & - & 0.047 \\
\hline Bertrand G & 27 & MAIPA & $\begin{array}{l}2^{\text {nd }} \& 3^{\text {rd }} \\
\text { trimester }\end{array}$ & $<50 \times 10^{9} / \mathrm{L}$ & $67 \%$ & $86 \%$ & $\begin{array}{c}23 \mathrm{IU} / \\
\mathrm{mL}\end{array}$ & - & $<0.001$ \\
\hline Kanhai HH, 1996 & 19 & PIFT & $\begin{array}{l}2^{\text {nd }} \& 3 \mathrm{rd} \\
\text { trimester }\end{array}$ & NR & - & - & - & - & NR \\
\hline
\end{tabular}

ELISA, enzyme-linked immunosorbent assay; MAIPA, monoclonal antibody immobilization of platelet antigen; NR, not reported;

NS, not significant; PIFT, platelet immunofluorescence test; $\mathrm{R}^{2}$, coefficient of determination.

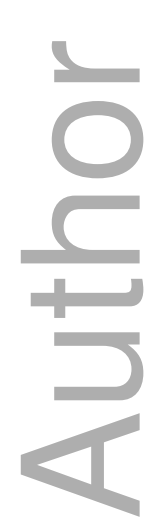

This article is protected by copyright. All rights reserved 

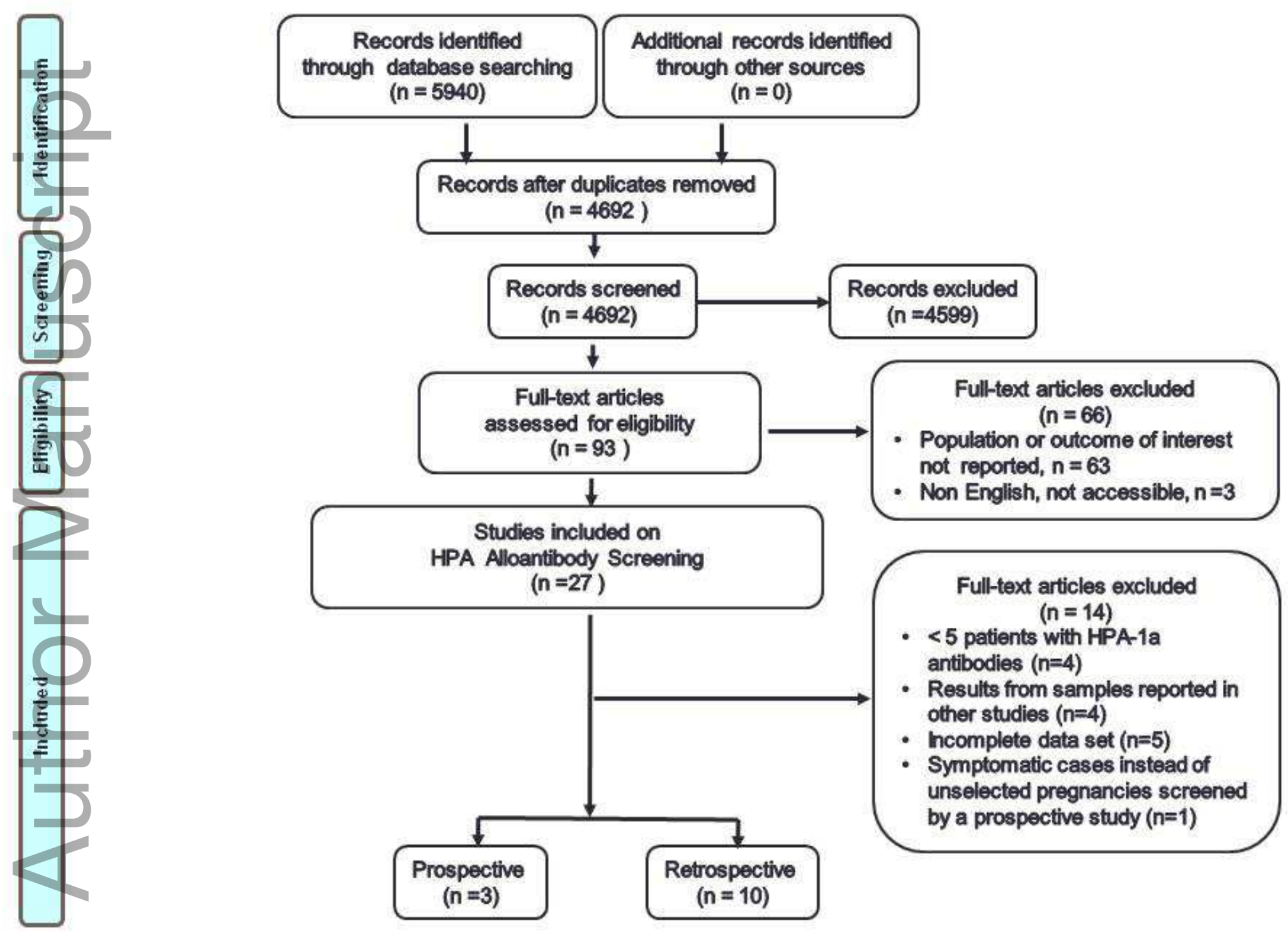

Figure 1 Flow diagram of included studies

This article is protected by copyright. All rights reserved 


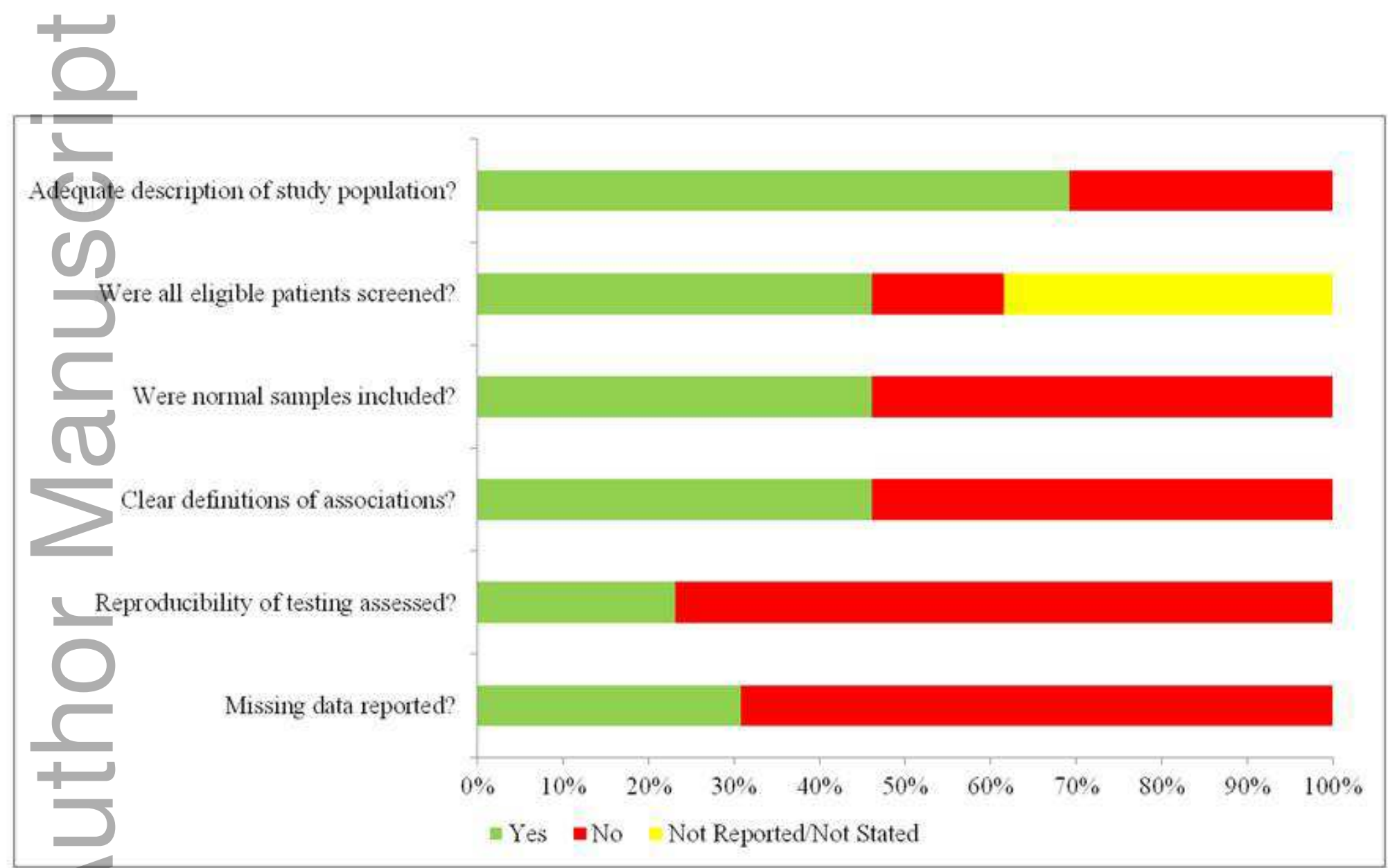

Figure 2 Quality assessment of included studies

This article is protected by copyright. All rights reserved 


\section{APPENDIX A: Search Strategy}

\section{MEDLINE}

1 thrombocytopenia, neonatal alloimmune/

2 thrombocytopenia/

3 limit 2 to "newborn infant (birth to 1 month)"

4 infant, newborn/ or infant, low birth weight/ or infant, small for gestational age/ or infant, very low birth weight/ or infant, extremely low birth weight/ or infant, postmature/ or infant, premature/ or infant, extremely premature/

5 Exp Fetus/

6 (fetus* or foetus* or fetal* or foetal* or neonat* or newborn* or infan* or prematur* or preemie* or "pre term" or "pre-term" or lbw or elbw or sga or vlbw or nicu*).mp.

73 or $(2$ and $(4$ or 5 or 6$))$

8 (((fetal or foetal or fetus* or foetus* or neonat*) adj5 thrombocytopen*) or NAIT or FNAIT or FMAIT).mp.

9 or/1,7-8

10 immunoglobulins, intravenous/

11 immunoglobulin g/ or IgG/ or Immunoglobulins/ or (immunoglobulin* or sandoglobulin* or sandoglobin* or "immune globulin*" or gamimmune or endobulin* or venoglobulini or gammagard or venoglobulin or "intraglobin $\mathrm{f}^{\text {" }}$ or intraglobin or "globulin-n" or "globulin n" or alphaglobin or privigen or "flebogamma dif" or gamunex or globulinn or venimmune or flebogamma or flebogammadif or gamastan or "gamma globulin*" or "gamma immunoglobulin*" or "gamma-globulin*" or gammagee or gammaglobulin* or gammar or gammimune or gamulin or globuman or Ig or igam or igc or immunogammaglobulin* or intragam or "intraglobin $\mathrm{f}^{\text {" or }}$ panglobulin* or tegelin* or "c 425" or c425 or "c-425" or cytotect or "gamimune n" or "gamma g" or "gamma globulin g" or gammagard or gammaglobulin* or "ig g" or IgG or octagam or pentaglobin or polygam or polyglobin or "gamma g1" or "gamma $\mathrm{g} 2 ") \cdot \mathrm{mp}$.

12 administration, intravenous/ or infusions, intravenous/ or injections, intravenous/ or (intravenous or iv or infusion* or administrat*).mp.

$13 \quad 11$ and 12 
14 (iveegam or gammonativ or "intravenous ig" or ivig or "glovenin i" or isiven or iveegam or ivega or veinoglobulin or vivaglobin* or gammonativ or kiovig or privigen).mp.

15 or/10,13-14

169 and 15

17 Antigens, Human Platelet/ or ("platelet-specific antigen*" or "antigen* plateletspecific" or (human adj5 platelet* adj5 antigen*) or (platelet adj5 alloantigen*) or HPA or HP-A).mp.

189 and 17

19 Maternal-Fetal Exchange/ or ("maternal-fetal exchange" or (transplacental adj5 (transfer* or exposure* or exchange*))).mp.

20 platelet transfusion/

21 blood component transfusion/ and blood platelets/

22 Blood Transfusion, Intrauterine/

23 ((intrauterine or fetus* or foetus* or fetal* or foetal* or cord or platelet*) adj5 transfusion*).mp.

24 or/19-23

259 and 24

26 exp adrenal cortex hormones/ or glucocorticoids/ or dexamethasone/ or dexamethasone isonicotinate/ or prednisone/

27 ("adrenal cortex hormone*" or "adrenal cortical hormone*" or ((adreno or adrenal) $\operatorname{adj} 2$ (cortex or cortical) adj2 steroid*) or corticosteroid* or adrenocortical or "cortical steroid*" or "cortico steroid" or glucocorticoid*).mp.

28 (dexamethasone or adrecort or adrenocot or "aeroseb dex" or aflucoson or aflucosone or alfalyl or anaflogistico or arcodexan or arcodexane or artrosone or azium or bidexol or calonat or cebedex or cetadexon or colofoam or corsona or cortastat or cortidex or cortidexason or cortidrona or cortidrone or cortisumman or dacortina fuerte or dacortine fuerte or dalalone or danasone or decacortin or decadeltosona or decadeltosone or decaderm or decadion or decadran or decadron or decadronal or decadrone or decaesadril or decaject or decameth or decamethasone or decasone or decaspray or decasterolone or decdan or decilone or decofluor or dectancyl or dekacort or delladec or deltafluoren or deltafluorene or dergramin or deronil or desacort or desacortone or desadrene or desalark or desameton or desametone or desigdron or "de-sone la" or "dexa cortisyl" or "dexa dabrosan" or "dexa korti" or 
"dexa scherosan" or "dexa scherozon" or "dexa scherozone" or dexacen or dexachel or dexacort or dexacortal or dexacorten or dexacortin or dexacortisyl or dexadabroson or dexadecadrol or dexadrol or dexagel or dexagen or dexahelvacort or dexakorti or dexalien or dexalocal or dexame or dexamecortin or dexameson or dexamesone or dexametason or dexamethasone or dexameth or dexamethasone or dexamethazon or dexamethasone or dexamethonium or dexamonozon or dexan or dexane or dexano or "dexa-p" or dexapot or dexascheroson or dexascherozon or dexascherozone or dexason or dexasone or dexinoral or dexionil or dexmethsone or dexona or dexone or dexpak or dextelan or dextrasone or dezone or dibasona or dexamethasone or esacortene or "ex s1" or exadion or exadione or firmalone or "fluormethyl prednisolone" or fluormethylprednisolon* or fluormone or fluorocort or fluorodelta or fluoromethylprednisolon* or fortecortin or gammacorten or gammacortene or grosodexon or grosodexone or hexadecadiol or hexadecadrol or hexadiol or hexadrol or isnacort or "isopto dex" or "isopto maxidex" or isoptodex or isoptomaxidex or "lokalison f" or loverine or luxazone or marvidione or maxidex or mediamethasone or megacortin or mephameson or mephamesone or metasolon or metasolone or methazon or methazone or methazonion or methazonione or methylfluorprednisolone or "metisone lafi" or mexasone or millicorten or millicortenol or "mk 125" or mymethasone or nisomethasona or novocort or "nsc 34521 " or nsc34521 or "oftandexa" or opticorten or opticortinol or oradexan or oradexon or oradexone or orgadrone or ozurdex or pidexon or policort or posurdex or "predni $f$ tabline" or "predni-f" or "prednisolone f" or prodexona or prodexone or sanamethasone or santenson or santeson or sawasone or solurex or spoloven or sterasone or thilodexine or triamcimetil or vexamet or visumetazone or visumethazone).mp.

29 (prednison* or ancortone or biocortone or colisone or cortan or corcortancyl or cortidelt or cortiprex or cutason or dacorten or dacortin or "de cortisyl" or decortancyl or decortin or decortine or decortisyl or dehydrocortisone or dekortin or delitisone or "dellacort a" or "delta 1 dehydrocortisone" or "delta cortelan" or "delta cortisone" or "delta dome" or "delta e" or "delta prenovis" or deltacorten* or deltacortisone or "delta-cortisone" or deltacortone or deltasone or deltison or deltisona or deltra or "di adreson" or diadreson or drazone or encorton or encortone or enkortolon or enkorton or fernisone or hostacortin or insone or kortancyl or "liquid pred" or lodotra or "mekorti" or meprison or metacortandracin or meticorten or meticortine or nisona or "sc 10023 " or nsc 10023 or orasone or orisane or panafcort or panasol or paracort or 
pehacort or precort or precortal or "predni tablinen" or "prednicen-m" or prednicorm or prednicot or prednidib or predniment or prednitone or pronison or pronisone or pronizone or pulmison or rayos or rectodelt or servisone or sone or steerometz orsterapred or ultracorten orurtilone or winpred).mp

30 dexamethasone acetate/ or (decadron or "decadron-la" or "dexi siozwo" or supertendin).mp.

31 "dexamethasone ester".mp

32 (auxiloson or auxison or dosauxison or "he 111" or he111 or voren).mp.

33 or $/ 26-32$

$34 \quad 9$ and 33

3516 or 18 or 25 or 34

\section{EMBASE}

1 neonatal alloimmune thrombocytopenia/

2 thrombocytopenia/

3 limit 2 to infant <to one year>

4 newborn/ or prematurity/ or "immature and premature labor"/ or low birth weight/ or extremely low birth weight/ or small for date infant/ or very low birth weight/

5 fetus/

6 (fetus* or foetus* or fetal* or foetal* or neonat* or newborn* or infan* or prematur* or preemie* or "pre term" or "pre-term" or lbw or elbw or sga or vlbw or nicu*).mp.

73 or $(2$ and $(4$ or 5 or 6$))$

$8 \quad((($ fetal or foetal or fetus* or foetus* or neonat*) adj5 thrombocytopen*) or NAIT or FNAIT or FMAIT).mp.

9 or $/ 1,7-8$

10 immunoglobulin/iv or immunoglobulin g/iv or immunoglobulin g1/iv or immunoglobulin g2/iv or immunoglobulin g2a/iv or immunoglobulin g2b/iv or immunoglobulin g3/iv or immunoglobulin g4/iv or ((immunoglobulin $\mathrm{g} /$ or IgG/ or Immunoglobulins/ or (immunoglobulin* or sandoglobulin* or sandoglobin* or "immune globulin*" or gamimmune or endobulin* or venoglobulini or gammagard or venoglobulin or "intraglobin $\mathrm{f}$ " or intraglobin or "globulin-n" or "globulin $\mathrm{n}$ " or alphaglobin or privigen or "flebogamma dif" or gamunex or globulinn or venimmune or flebogamma or flebogammadif or gamastan or "gamma globulin*" or "gamma 
immunoglobulin*" or "gamma-globulin*" or gammagee or gammaglobulin* or gammar or gammimune or gamulin or globuman or Ig or igam or igc or immunogammaglobulin* or intragam or "intraglobin f" or panglobulin* or tegelin* or "c 425 " or c 425 or "c-425" or cytotect or "gamimune n" or "gamma g" or "gamma globulin g" or gammagard or gammaglobulin* or "ig g" or IgG or octagam or pentaglobin or polygam or polyglobin or "gamma g1" or "gamma g2")) and iv.fs.).mp.

11 (iveegam or gammonativ or "intravenous ig" or ivig or "glovenin i" or isiven or iveegam or ivega or veinoglobulin or vivaglobin* or gammonativ or kiovig or privigen).mp.

12 or/10-11

139 and 12

14 thrombocyte antigen/ or ("platelet-specific antigen*" or "antigen* platelet-specific" or (human adj5 platelet* adj5 antigen*) or (platelet adj5 alloantigen*) or HPA or HP-

A).mp.

159 and 14

16 fetomaternal transfusion/ or ("maternal-fetal exchange" or (transplacental adj5 (transfer* or exposure* or exchange*))).mp.

17 thrombocyte transfusion/ or (platelet adj2 transfus*).mp.

18 (blood component therapy/ or blood transfusion/) and (thrombocyte/ or platelet*.ti,ab.)

19 intrauterine blood transfusion/

20 ((intrauterine or fetus* or foetus* or fetal $^{*}$ or foetal* or cord or platelet*) adj5 transfusion*).mp.

21 or/16-20[****Transfusion terms****] ()

$22 \quad 9$ and 21

23 exp corticosteroid/ or glucocorticoid/ or dexamethasone/ or dexamethasone isonicotinate/ or prednisone/ or ("adrenal cortex hormone*" or "adrenal cortical hormone*" or ((adreno or adrenal) adj2 (cortex or cortical) adj 2 steroid*) or corticosteroid* or adrenocortical or "cortical steroid*" or "cortico steroid" or glucocorticoid*).mp.

24 (dexamethasone or adrecort or adrenocot or "aeroseb dex" or aflucoson or aflucosone or alfalyl or anaflogistico or arcodexan or arcodexane or artrosone or azium or bidexol or calonat or cebedex or cetadexon or colofoam or corsona or cortastat or cortidex or cortidexason or cortidrona or cortidrone or cortisumman or dacortina fuerte or dacortine fuerte or dalalone or danasone or decacortin or decadeltosona or 
decadeltosone or decaderm or decadion or decadran or decadron or decadronal or decadrone or decaesadril or decaject or decameth or decamethasone or decasone or decaspray or decasterolone or decdan or decilone or decofluor or dectancyl or dekacort or delladec or deltafluoren or deltafluorene or dergramin or deronil or desacort or desacortone or desadrene or desalark or desameton or desametone or desigdron or "de-sone la" or "dexa cortisyl" or "dexa dabrosan" or "dexa korti" or "dexa scherosan" or "dexa scherozon" or "dexa scherozone" or dexacen or dexachel or dexacort or dexacortal or dexacorten or dexacortin or dexacortisyl or dexadabroson or dexadecadrol or dexadrol or dexagel or dexagen or dexahelvacort or dexakorti or dexalien or dexalocal or dexame or dexamecortin or dexameson or dexamesone or dexametason or dexamethasone or dexameth or dexamethasone or dexamethazon or dexamethasone or dexamethonium or dexamonozon or dexan or dexane or dexano or "dexa-p" or dexapot or dexascheroson or dexascherozon or dexascherozone or dexason or dexasone or dexinoral or dexionil or dexmethsone or dexona or dexone or dexpak or dextelan or dextrasone or dezone or dibasona or dexamethasone or esacortene or "ex s1" or exadion or exadione or firmalone or "fluormethyl prednisolone" or fluormethylprednisolon* or fluormone or fluorocort or fluorodelta or fluoromethylprednisolon* or fortecortin or gammacorten or gammacortene or grosodexon or grosodexone or hexadecadiol or hexadecadrol or hexadiol or hexadrol or isnacort or "isopto dex" or "isopto maxidex" or isoptodex or isoptomaxidex or "lokalison f" or loverine or luxazone or marvidione or maxidex or mediamethasone or megacortin or mephameson or mephamesone or metasolon or metasolone or methazon or methazone or methazonion or methazonione or methylfluorprednisolone or "metisone lafi" or mexasone or millicorten or millicortenol or "mk 125" or mymethasone or nisomethasona or novocort or "nsc 34521" or nsc34521 or "oftandexa" or opticorten or opticortinol or oradexan or oradexon or oradexone or orgadrone or ozurdex or pidexon or policort or posurdex or "predni f tabline" or "predni-f" or "prednisolone f" or prodexona or prodexone or sanamethasone or santenson or santeson or sawasone or solurex or spoloven or sterasone or thilodexine or triamcimetil or vexamet or visumetazone or visumethazone).mp.

25 (prednison* or ancortone or biocortone or colisone or cortan or corcortancyl or cortidelt or cortiprex or cutason or dacorten or dacortin or "de cortisyl" or decortancyl or decortin or decortine or decortisyl or dehydrocortisone or dekortin or delitisone or "dellacort a" or "delta 1 dehydrocortisone" or "delta cortelan" or "delta cortisone" or 
"delta dome" or "delta e" or "delta prenovis" or deltacorten* or deltacortisone or "delta-cortisone" or deltacortone or deltasone or deltison or deltisona or deltra or "di adreson" or diadreson or drazone or encorton or encortone or enkortolon or enkorton or fernisone or hostacortin or insone or kortancyl or "liquid pred" or lodotra or "mekorti" or meprison or metacortandracin or meticorten or meticortine or nisona or "sc $10023^{\prime \prime}$ or nsc 10023 or orasone or orisane or panafcort or panasol or paracort or pehacort or precort or precortal or "predni tablinen" or "prednicen-m" or prednicorm or prednicot or prednidib or predniment or prednitone or pronison or pronisone or pronizone or pulmison or rayos or rectodelt or servisone or sone or steerometz orsterapred or ultracorten orurtilone or winpred).mp.

26 dexamethasone acetate/ or (decadron or "decadron-la" or "dexi siozwo" or supertendin).mp.

27 "dexamethasone ester".mp.

28 (auxiloson or auxison or dosauxison or "he 111" or he111 or voren).mp.

29 or $/ 23-28$

$30 \quad 9$ and 29

$31 \quad 13$ or 15 or 22 or 30

\section{Cochrane Central Register of Controlled Trials}

1 thrombocytopenia, neonatal alloimmune/ or neonatal alloimmune thrombocytopenia/ 2 thrombocytopenia/

3 infant, newborn/ or infant, low birth weight/ or infant, small for gestational age/ or infant, very low birth weight/ or infant, extremely low birth weight/ or infant, postmature/ or infant, premature/ or infant, extremely premature/ or newborn/ or prematurity/ or "immature and premature labor"/ or low birth weight/ or extremely low birth weight/ or small for date infant/ or very low birth weight/

4 exp fetus/

5 (fetus* or foetus* or fetal* or foetal* or neonat* or newborn* or infan* or prematur* or preemie* or "pre term" or "pre-term" or lbw or elbw or sga or vlbw or nicu*).mp.

62 and ( 3 or 4 or 5$)$

$7 \quad((($ fetal or foetal or fetus* or foetus* or neonat*) adj5 thrombocytopen*) or NAIT or FNAIT or FMAIT).mp.

$8 \quad 1$ or 6 or 7

This article is protected by copyright. All rights reserved 


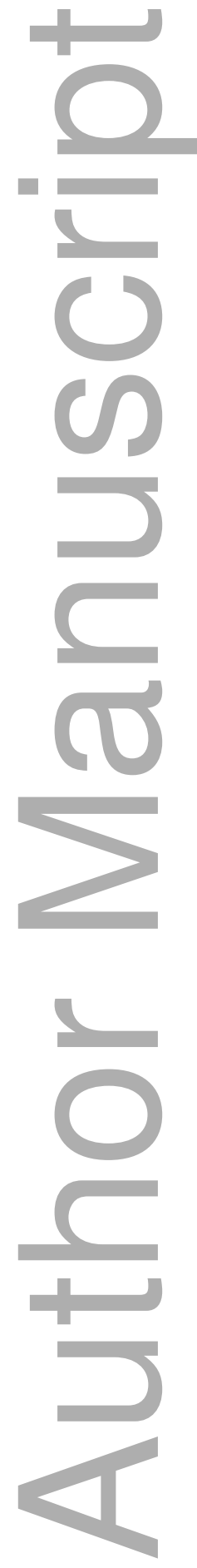

This article is protected by copyright. All rights reserved 


\section{Appendix B Characteristics and Outcomes of Samples Collected}

\begin{tabular}{|c|c|c|c|c|c|c|c|c|}
\hline $\begin{array}{c}\text { Author, } \\
\text { Year; } \\
\text { Country, } \\
\text { Center }\end{array}$ & $\begin{array}{l}\text { Implicated } \\
\text { HPA } \\
\text { antigen }\end{array}$ & $\begin{array}{c}\text { Method of } \\
\text { antibody } \\
\text { determination }\end{array}$ & $\begin{array}{c}\text { Antibody } \\
\text { Concentration } \\
\text { Threshold, }\end{array}$ & $\begin{array}{l}\text { Frequency } \\
\text { of antibody } \\
\text { screening }\end{array}$ & $\begin{array}{c}\text { \# screened / } \\
\text { \# of pregnant } \\
\text { women with } \\
\text { HPA antibody / } \\
\text { \# of pregnancies } \\
\text { included }\end{array}$ & $\begin{array}{c}\text { Platelet } \\
\text { count } \\
\text { that } \\
\text { correlated } \\
\text { with } \\
\text { antibody titre }\end{array}$ & $\begin{array}{c}\text { Sensitivity (\%)/ } \\
\text { Specificity (\%)/ } \\
\text { PPV (\%)/ } \\
\text { NPV (\%) }\end{array}$ & Summary \\
\hline \multicolumn{9}{|c|}{ Prospective } \\
\hline $\begin{array}{l}\text { Killie M, } \\
2008 ; \\
\text { Norway, } \\
\text { single cente }\end{array}$ & $1 \mathrm{a}$ & $\begin{array}{c}\text { MAIPA } \\
\text { PIFT }\end{array}$ & $>3 \mathrm{IU} / \mathrm{mL}$ & $\begin{array}{c}\text { Every } 4 \\
\text { weeks }\end{array}$ & $1,990 / 161 / 161$ & $<50 \times 10^{9} / \mathrm{L}$ & $\begin{array}{l}93 / \\
63 / \\
54 / \\
95\end{array}$ & $\begin{array}{c}\text { The maternal } \\
\text { antibody level } \\
\text { (IU/mL) at } \\
\text { delivery } \\
\text { correlated with } \\
\text { the degree of } \\
\text { FNAIT } \\
(\mathrm{p}<0.001) \text {. }\end{array}$ \\
\hline $\begin{array}{l}\text { Bessos H, } \\
2005 ; \\
\text { Scotland, } \\
\text { multi cente }\end{array}$ & 1a & ELISA & NR & $\begin{array}{c}\text { Samples } \\
\text { obtained } \\
\text { from various } \\
\text { gestational } \\
\text { ages }\end{array}$ & $327 / 28 / 22$ & NR & NR & $\begin{array}{c}\text { The maternal } \\
\text { antibody level } \\
\text { did not correlate } \\
\text { with the degree } \\
\text { of FNAIT } \\
\text { (R=-0.046). }\end{array}$ \\
\hline
\end{tabular}




\begin{tabular}{|c|c|c|c|c|c|c|c|c|}
\hline $\begin{array}{l}\text { Williamson } \\
\text { L, 1998; } \\
\text { UK, } \\
\text { multi center }{ }^{4}\end{array}$ & 1a & MAIPA & $\geq 1: 32$ & $\begin{array}{c}\text { HLA- } \\
\text { DRB3*0101 } \\
\text { positive: } \\
\text { week 26, 30, } \\
36 ; \\
\text { HLA- } \\
\text { DRB3*0101 } \\
\text { negative: } \\
\text { week 28-34 }\end{array}$ & $24,417 / 46 / 387$ & $<50 \times 10^{9} / \mathrm{L}$ & $\begin{array}{l}\mathrm{NR} / \\
\mathrm{NR} / \\
75 / \\
88\end{array}$ & $\begin{array}{c}\text { The maternal } \\
\text { antibody titre at } \\
\text { last trimester } \\
\text { correlated with } \\
\text { the degree of } \\
\text { FNAIT } \\
(\mathrm{p}=0.004) .\end{array}$ \\
\hline \multicolumn{9}{|c|}{ Retrospective } \\
\hline $\begin{array}{l}\text { Bertrand G, } \\
2014 ; \\
\text { France, } \\
\text { single } \\
\text { center }^{12}\end{array}$ & $1 \mathrm{a}$ & MAIPA & $>23 \mathrm{IU} / \mathrm{mL}$ & $\begin{array}{c}\text { Every 3-5 } \\
\text { weeks }\end{array}$ & $55 / 55 / 55$ & $<50 \times 10^{9} / \mathrm{L}$ & $\begin{array}{l}76 / \\
79 / \\
67 / \\
86\end{array}$ & $\begin{array}{c}\text { The maternal } \\
\text { antibody level } \\
\text { (IU/mL) during } \\
\text { pregnancy } \\
\text { correlated with } \\
\text { the degree of } \\
\text { FNAIT } \\
(\mathrm{p}<0.0001) .\end{array}$ \\
\hline $\begin{array}{l}\text { Sainio } \mathrm{S}, \\
2013 ; \\
\text { Finland, } \\
\text { multi center }^{10}\end{array}$ & $1 \mathrm{a}$ & MAIPA & NR & $\begin{array}{c}\text { Index } \\
\text { pregnancies, } \\
\text { postnatally; }\end{array}$ & $129 / 84 / 129$ & $<20 \times 10^{9} / \mathrm{L}$ & Subsequent pregnancies & $\begin{array}{c}\text { Index } \\
\text { pregnancies: } \\
\text { The maternal } \\
\text { antibody level }\end{array}$ \\
\hline
\end{tabular}




\begin{tabular}{|c|c|c|c|c|c|c|c|c|}
\hline 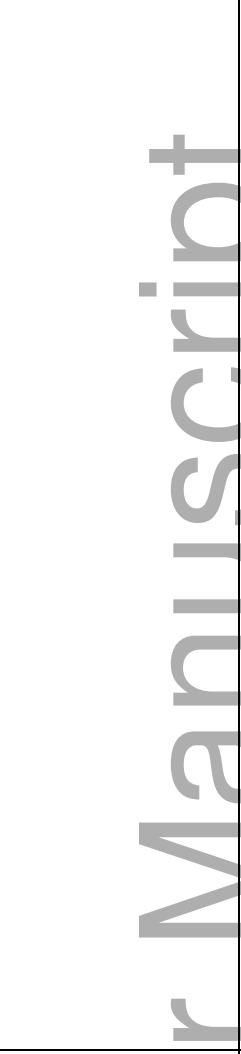 & & & & $\begin{array}{l}\text { Subsequent } \\
\text { pregnancies, } \\
\text { first and } \\
\text { second } \\
\text { trimesters }\end{array}$ & & & $\begin{array}{l}\mathrm{NR} / \\
\mathrm{NR} / \\
90 / \\
31\end{array}$ & $\begin{array}{c}\text { (IU/mL) } \\
\text { postnatally did } \\
\text { not correlate } \\
\text { with the degree } \\
\text { of FNAIT } \\
\text { (p=0.074). } \\
\text { Subsequent } \\
\text { pregnancies: } \\
\text { The maternal } \\
\text { antibody titers at } \\
\text { second trimester } \\
\text { correlated with } \\
\text { the degree of } \\
\text { FNAIT } \\
\text { (p=0.046). }\end{array}$ \\
\hline $\begin{array}{l}\text { Giers G, } \\
\text { 2010; } \\
\text { Germany, } \\
\text { single } \\
\text { center }^{13}\end{array}$ & $\begin{array}{c}\text { a, 3a, 4b, } \\
5 \mathrm{~b}\end{array}$ & MAIPA & NR & $\begin{array}{l}\text { Prior to } \\
\text { intrauterine } \\
\text { transfusion }\end{array}$ & $57 / 57 / 57$ & $\mathrm{NR}$ & NR & $\begin{array}{c}\text { No quantitative } \\
\text { measurements }\end{array}$ \\
\hline $\begin{array}{l}\text { Ghevaert C, } \\
2007\end{array}$ & 1a & $\begin{array}{c}\text { MAIPA } \\
\text { CL }\end{array}$ & $>30 \mathrm{IU} / \mathrm{mL}$ & $\begin{array}{c}\text { Index } \\
\text { pregnancies, }\end{array}$ & $133 / 117 / 133$ & $<20 \times 10^{9} / \mathrm{L}$ & Subsequent pregnancies & $\begin{array}{c}\text { Index } \\
\text { pregnancies: }\end{array}$ \\
\hline
\end{tabular}




\begin{tabular}{|c|c|c|c|c|c|c|c|c|}
\hline $\begin{array}{l}\text { UK, multi } \\
\text { center }^{7}\end{array}$ & & & & $\begin{array}{l}\text { postnatally; } \\
\text { Subsequent } \\
\text { pregnancies, } \\
\text { first, second } \\
\text { and third } \\
\text { trimesters }\end{array}$ & & & $\begin{array}{c}\text { NR/ } \\
\text { NR/ } \\
90 / \\
66\end{array}$ & $\begin{array}{c}\text { The maternal } \\
\text { antibody level } \\
\text { (IU/mL) } \\
\text { postnatally did } \\
\text { not correlate } \\
\text { with the degree } \\
\text { of FNAIT } \\
\text { (p-value NR). } \\
\text { Subsequent } \\
\text { pregnancies: } \\
\text { The maternal } \\
\text { antibody level } \\
\text { (IU/mL) at } \\
\text { second trimester } \\
\text { correlated with } \\
\text { the degree of } \\
\text { FNAIT } \\
\text { (p-value NR) }\end{array}$ \\
\hline $\begin{array}{l}\text { Killie MK, } \\
2007 \text {; } \\
\text { Norway, } \\
\text { multi center }\end{array}$ & 1a & MAIPA & NR & At delivery & $108 / 102 / 102$ & $<25 \times 10^{9} / \mathrm{L}$ & NR & $\begin{array}{c}\text { The maternal } \\
\text { antibody level } \\
\text { (IU/mL) at } \\
\text { delivery } \\
\text { correlated with }\end{array}$ \\
\hline
\end{tabular}




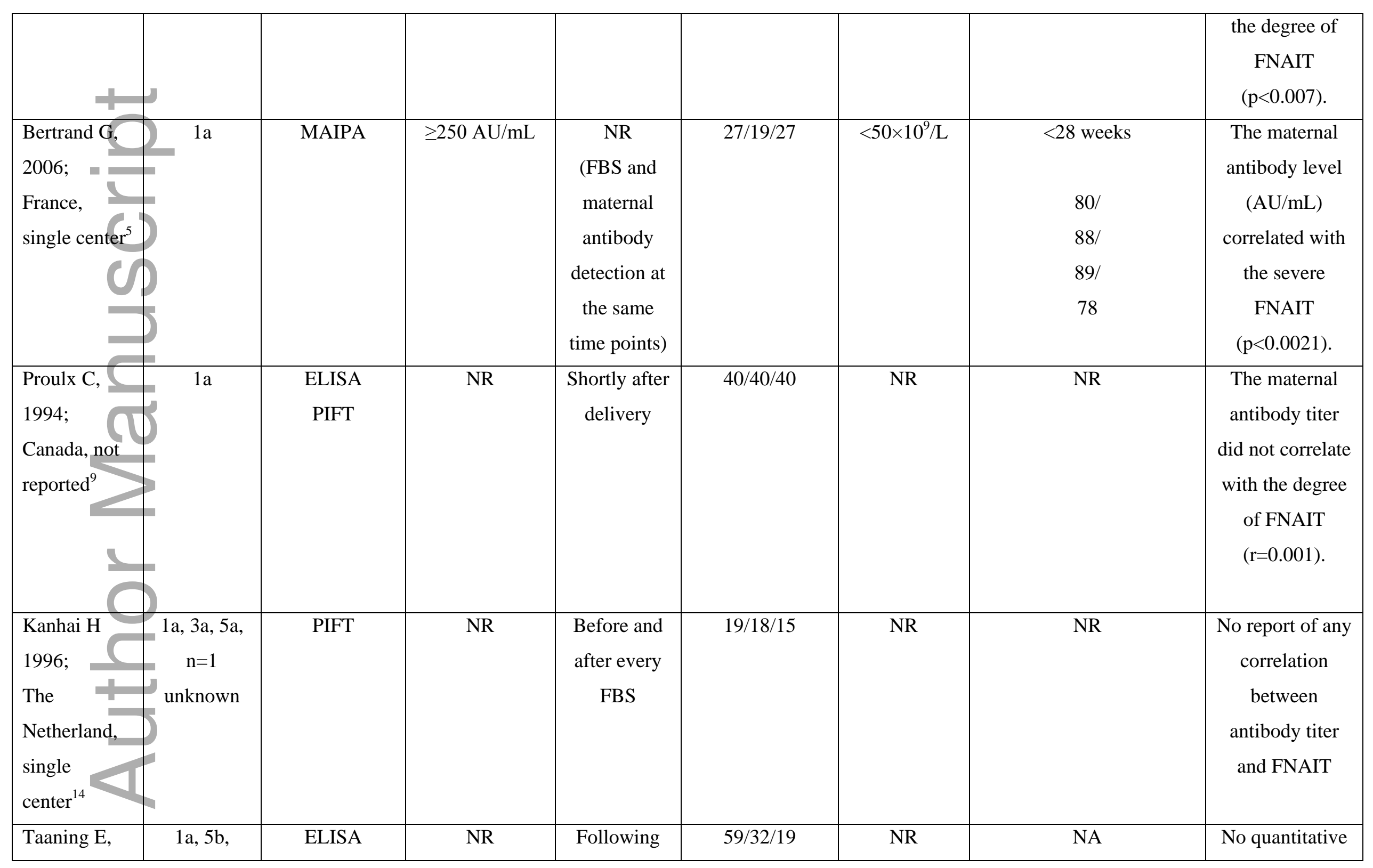




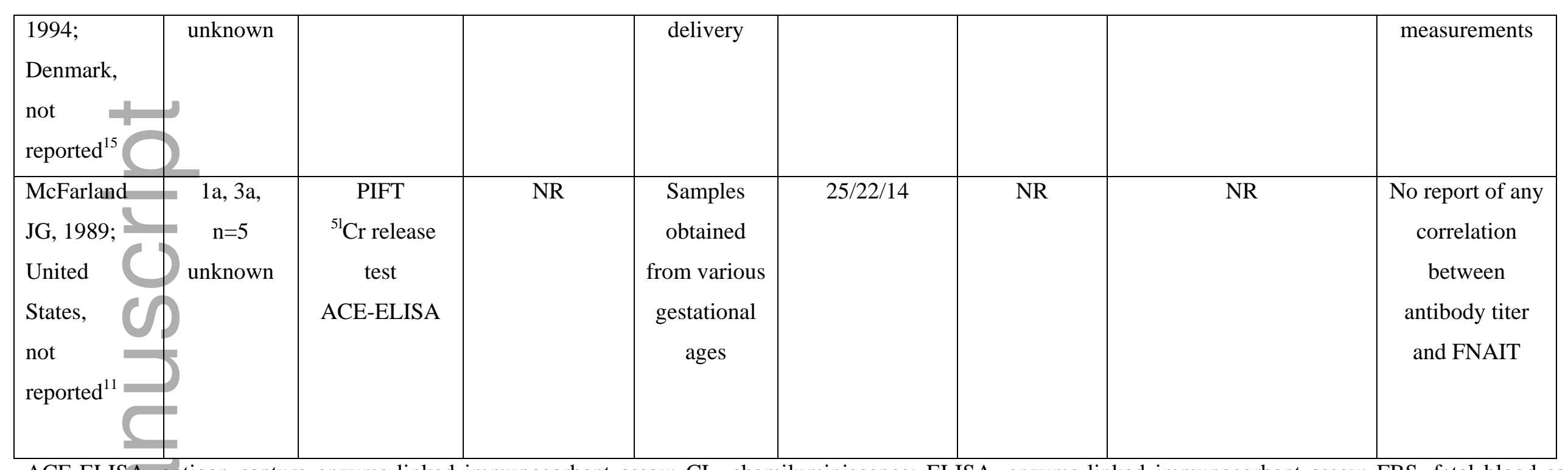

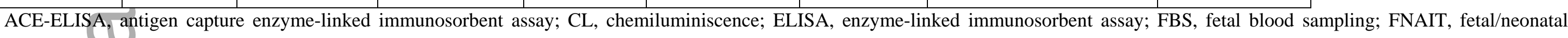

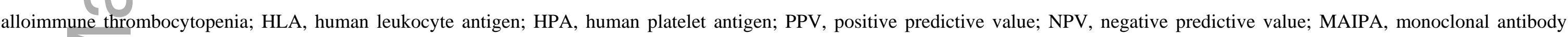
immobilization of platelet antigen; PIFT, platelet immunofluorescence test; NA, not applicable; NR, not reported

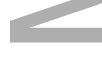

\section{Appendix C Excluded studies in the final analysis}

\begin{tabular}{|l|l|}
\hline Author, Year & Reasons for exclusion \\
\hline Fratellanza G, $2006^{25}$ & Screening of selected pregnancies \\
\hline Davoren A, 2003 & Anti-HPA-1a (3 patients) \\
\hline Jaegtvik S, 2000 & Anti-HPA-1a (24 patients); data reported in Killie $2008^{2}$ \\
\hline Ohto H, 2000 & Anti-HPA-5b; no anti-HPA-1a \\
\hline Doughty HA, $1995^{28}$ & Anti-HPA-1a (2 patients) \\
\hline
\end{tabular}




\begin{tabular}{|c|c|}
\hline Panzer S, $1995^{23}$ & Anti-HPA-5b; no anti-HPA-1a \\
\hline Blanchette V, $1990^{26}$ & Anti-HPA-1a (3 patients, 2 patients prior to birth, 1 postpartum) \\
\hline Bertrand G, $2011^{17}$ & Anti-HPA-1a (75 patients). The same samples have been reported in Bertrand $2014^{12}$ \\
\hline Killie MK, $2010^{16}$ & Data already included in Killie $2008^{2}$ \\
\hline Bessos $\mathrm{H}, 2008^{18}$ & Anti-HPA-1a (26 patients); results from 12 samples has been reported in Killie $2008^{2}$ \\
\hline Kaplan C $1988^{29}$ & Anti-HPa-1a (5 patients) \\
\hline Ohto $\mathrm{H}, 2004^{22}$ & Anti-HPA-4b and anti-HPA-5b; no anti-HPA-1a \\
\hline Kurtz M, $1999^{21}$ & Anti-HPA-5b; no anti-HPA-1a \\
\hline Mawas F, $1997^{20}$ & 14 of 27 samples (all anti-HPA-1a) were from Williamson $1998^{4}$ \\
\hline
\end{tabular}

HPA indicates human platelet antigen.

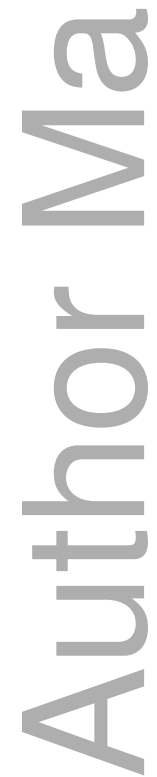




\section{University Library}

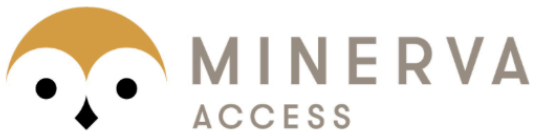

A gateway to Melbourne's research publications

Minerva Access is the Institutional Repository of The University of Melbourne

\section{Author/s:}

Kjaer, M;Bertrand, G;Bakchoul, T;Massey, E;Baker, JM;Lieberman, L;Tanael, S;Greinacher, A;Murphy, MF;Arnold, DM;Baidya, S;Bussel, J;Hume, H;Kaplan, C;Oepkes, D;Ryan, G;Savoia, H;Shehata, N;Kjeldsen-Kragh, J;Allard, S;Bianco, C;Callum, J;Compernolle, V;Fergusson, D;Fung, M;Greinacher, A;Hume, H;Lieberman, L;Murphy, MF;Nahirniak, S;Pavenski, K;Pink, J;Shehata, N;So-Osman, C;Stanworth, SJ;Szczepiorkowski, ZM;Tanael, S;Wood, E

Title:

Maternal HPA-1a antibody level and its role in predicting the severity of Fetal/Neonatal Alloimmune Thrombocytopenia: a systematic review

\section{Date:}

2019-01-01

\section{Citation:}

Kjaer, M., Bertrand, G., Bakchoul, T., Massey, E., Baker, J. M., Lieberman, L., Tanael, S., Greinacher, A., Murphy, M. F., Arnold, D. M., Baidya, S., Bussel, J., Hume, H., Kaplan, C., Oepkes, D., Ryan, G., Savoia, H., Shehata, N., Kjeldsen-Kragh, J. ,... Wood, E. (2019). Maternal HPA-1a antibody level and its role in predicting the severity of Fetal/Neonatal Alloimmune Thrombocytopenia: a systematic review. VOX SANGUINIS, 114 (1), pp.79-94. https://doi.org/10.1111/vox.12725.

Persistent Link:

http://hdl.handle.net/11343/284920 